WIOLETTA KAZIMIERSKA-JERZYK

Instytut Filozofii

Uniwersytetu Łódzkiego

\title{
DZIEŁA MISTRZÓW TRADYCYJNEGO MALARSTWA SZTALUGOWEGO JAKO INSPIRACJE WSPÓŁCZESNYCH MURALI - PROJEKT „OFF GALERIA” (2015)
}

\begin{abstract}
T esienią 2015 r. z inicjatywy Fundacji Urban Forms (dalej FUF) ${ }^{1}$ zrealizowano w Łodzi projekt „Off Galeria”, w wyniku którego na obszarze Starego Polesia $^{2}$ powstały trzy wielkoformatowe malowidła ścienne inspirowane dziełami sztuki ze zbiorów malarstwa polskiego znajdujących się w Muzeum Miasta Łodzi. Prace te są - w odróżnieniu od wielu innych łódzkich murali nowego typu ${ }^{3}$ - rezultatem szerszej koncepcji, zakładającej kooperację FUF
\end{abstract}

${ }^{1}$ FUF zajmuje się animacją sztuki miejskiej w Łodzi, a także w innych polskich miastach. Zrealizowała m.in. projekty rewitalizacji w zabytkowej przestrzeni Starego Miasta w Gdańsku „Ogarna 2.0” i „Nowa Szeroka” (2013-15), a także Program Partycypacji Społecznej w Łodzi w 2015 r. Formalnie istnieje pod tą nazwą od 2011 r., zob.: A. Gralińska-Toborek, W. Kazimierska-Jerzyk, Doświadczenie sztuki w przestrzeni miejskiej. Galeria Urban Forms 2011-2013 / Experience of Art in Urban Space. Urban Forms Gallery 2011-2013, tłum. M. Koniarek, Łódź 2014, s. 5.

${ }^{2}$ Stare Polesie jest dziś częścią osiedla administracyjnego (tzw. jednostki pomocniczej gminy według obecnej nomenklatury Urzędu Miasta Łodzi; ostatni podział administracyjny, w którym istniały dzielnice, obowiązywał w latach 1960-1992). Nazwa ta odnosi się do najwcześniej zurbanizowanego obszaru dawnej dzielnicy Polesie. Obecnie Stare Polesie uchodzi za jedną z najbardziej zaniedbanych części miasta, ale jest jednocześnie obszarem zabytkowym o wyjątkowych walorach. To także okolica, w której silnie działa lokalna społeczność, koncentrując swą uwagę na zachowaniu wartości dziedzictwa historycznego oraz na jak najbardziej efektywnym wdrażaniu procesów rewitalizacyjnych. Zob. np.: I. Adamczewska, Stare Polesie. Aktywiści zmieniaja je bez pomocy miasta, „Gazeta Wyborcza” 27.06.2014, tekst dostępny online: htt http://lodz.wyborcza.pl/lodz/1,35153,16225354,Stare_Polesie_Aktywisci_zmieniaja_je_bez_pomocy_miasta.html; działalność nieformalnego zrzeszenia instytucji i osób działających na Starym Polesiu pod nazwą Współ-dzielnia Staropoleska, https://www. facebook.com/wspoldzielniastaropoleska (dostęp: 17.01.2016).

3 Łódź słynie też z wielkoformatowych ściennych pseudoreklam z okresu PRL, powstających od lat pięćdziesiątych do lat osiemdziesiątych włącznie, cenionych jako oryginalny wkład w estetyczną tożsamość miasta i wykonywanych m.in. przez artystów akademickich, 
z lokalnymi podmiotami ${ }^{4}$ oraz proces partycypacji mieszkańców okolic, w których stworzono dzieła. Idea ta zyskała wsparcie Narodowego Centrum Kultury w ramach programu „Kultura dostępna”, dzięki czemu organizatorzy dysponowali nie tylko ściśle określonym budżetem, lecz byli także zobowiązani konkretnymi założeniami, harmonogramem oraz procesem ewaluacyjnym. Na „Off Galerię” składają się następujące prace: (1) mural na szczytowej ścianie kamienicy przy ul. Pogonowskiego 12, Madonna astronautów, namalowany przez Egona Fietke (właśc. Andrzej Miastkowski), inspirowany Madonnq astronautów Wacława Kondka5; (2) mural na szczytowej ścianie kamienicy przy ul. Pogonowskiego 35 stworzony przez duet artystów

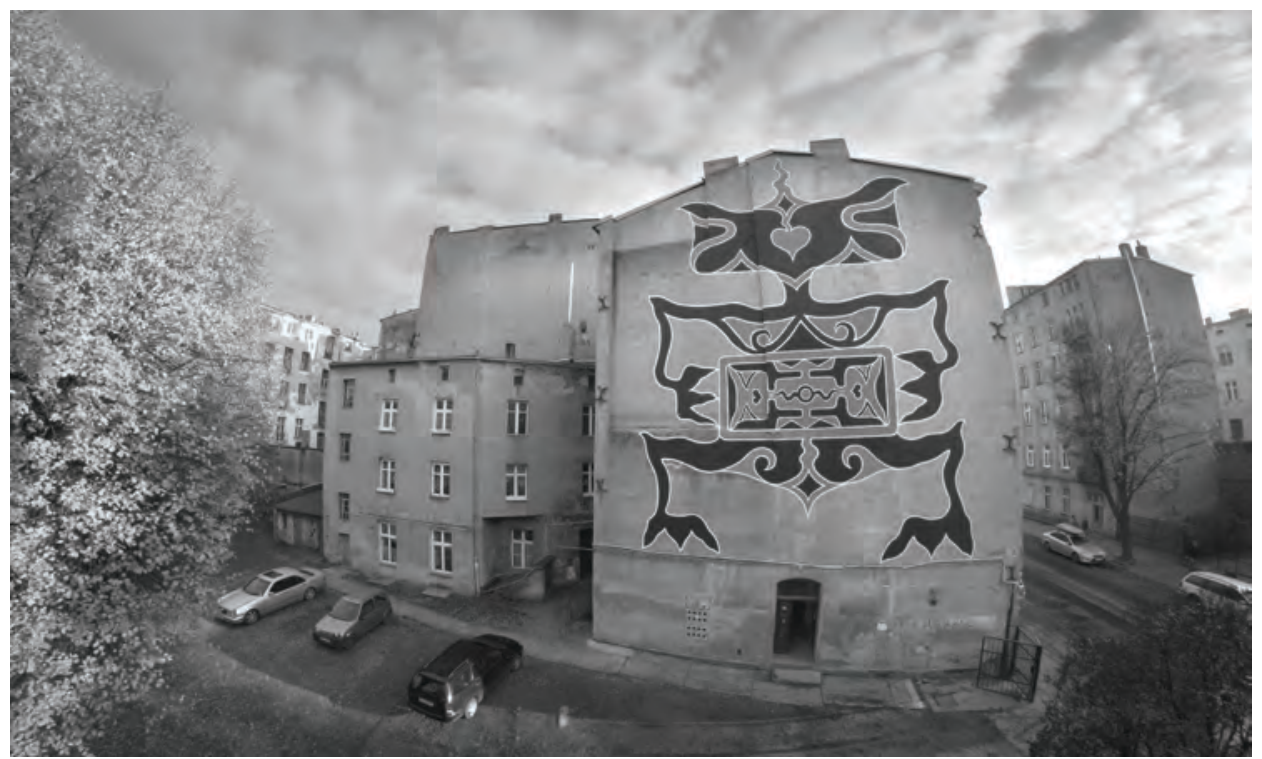

Ryc. 47. Egon Fietke, mural na szczytowej ścianie kamienicy przy ul. Pogonowskiego 12, Madonna astronautów, „Off Galeria”, 2015

zob. B. Stępień, Łódzkie murale. Niedoceniona grafika użytkowa PRL-u, Łódź 2010. Autor tejże monografii zinwentaryzował także późniejsze, mniej liczne murale okresu transformacji, zob.: Łódzkie murale [witryna internetowa], http://www.murale.mnc.pl/m_072.htm_(dostęp: 17.01.2016). Warto odnotować, że jest to jednoosobowa, prywatna inicjatywa, chroniąca pamięć o tego typu twórczości. Żadne z tych dzieł nie jest objęte opieką konserwatorską i nie przedstawiono dotąd miejskiego programu ich ochrony lub choćby gruntownego spisu czy klasyfikacji.

4 Muzeum Miasta Łodzi, Stowarzyszenie Społecznie Zaangażowani, Instytut Filozofii Uniwersytetu Łódzkiego.

${ }^{5}$ Wacław Kondek, Madonna astronautów, 1962, olej na płótnie, wymiary $93 \cdot 73$ cm, Muzeum Miasta Łodzi. 


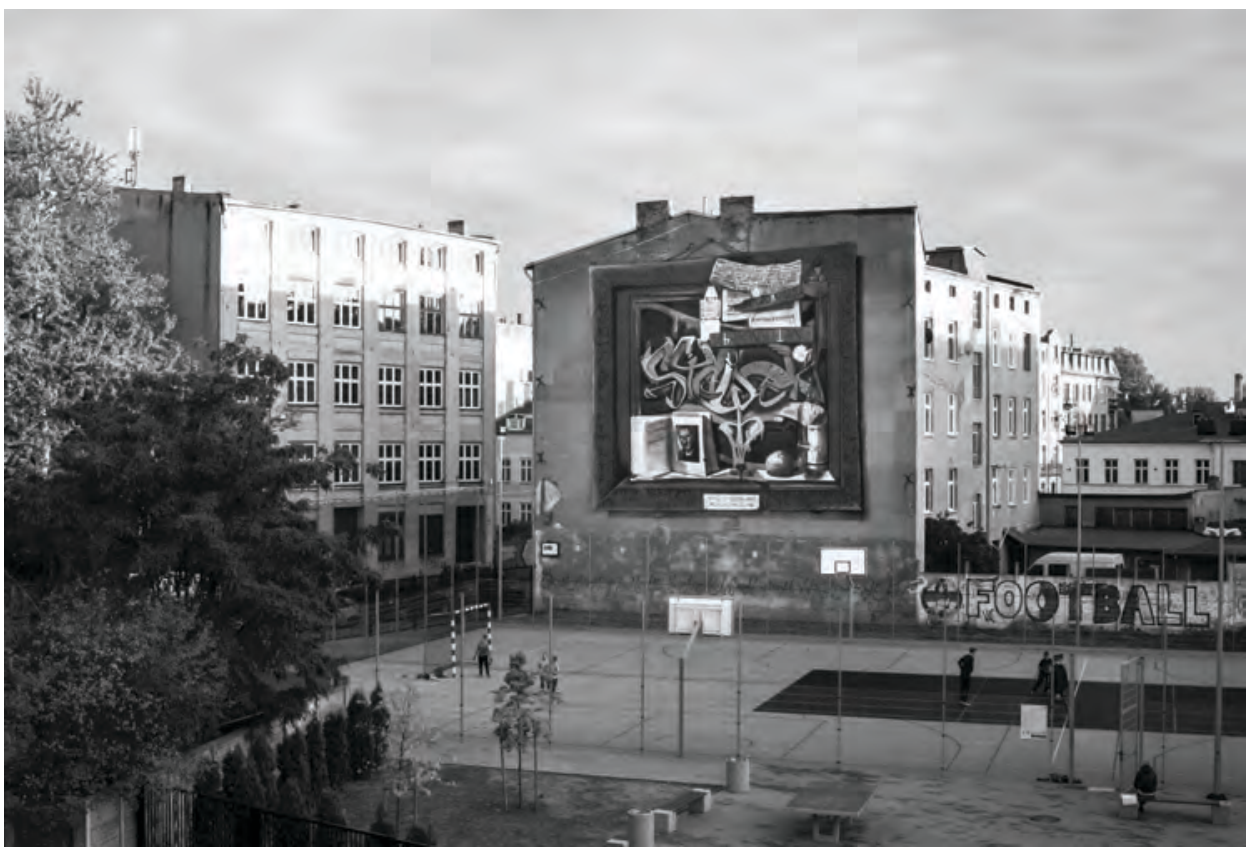

Ryc. 48. Meisal461, Ovca, mural na szczytowej ścianie kamienicy przy ul. Pogonowskiego 35, Dyskusja o muralach, „Off Galeria”, 2015

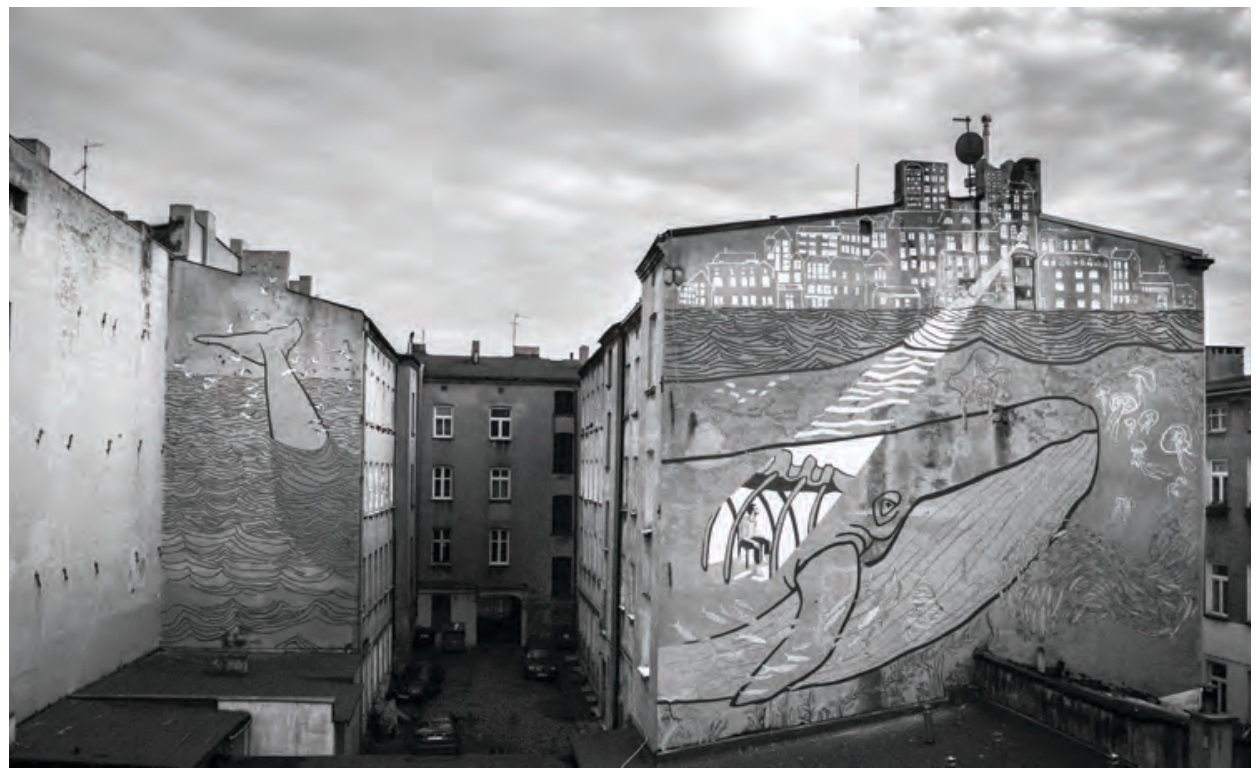

Ryc. 49. Aleksandra Adamczuk, Paulina Nawrot, dwuczęściowy mural na szczytowych ścianach oficyn posesji przy ul. Legionów 49, Jonasz, „Off Galeria”, 2015 
graffiti z grupy NTK ${ }^{6}$ Meisala461 (właśc. Sławomir Krysiak) i Ovcę (właśc. Paweł Hert), Dyskusja o muralach, nawiązujący do obrazu Jerzego Krawczyka Myśli o działaniu, myśli o myśleniu ; (3) dwuczęściowe malowidło zrealizowane wspólnie przez Aleksandrę Adamczuk i Paulinę Nawrot na dwóch szczytowych ścianach oficyn posesji przy ul. Legionów 49, oddzielonych od siebie przestrzenią podwórka (widocznych od strony ul. Mielczarskiego), Jonasz, nawiązujące do dzieła Adama Muszki Chederowe wspomnienia ${ }^{8}$.

\section{INSPIRACJE}

Tere eresa Latuszewska-Syrda", opracowując koncepcję „Off Galerii”, bezpośrednio inspirowała się Dulwich Outdoor Gallery, formalnie zaprezentowaną jako kolekcja dzieł street artu podczas festiwalu „Baroque The Streets: Dulwich Street Art Festival 2013" w dniach 10-19 maja 2013 r. Sam festiwal był rezultatem współpracy pomiędzy Street Art London ${ }^{10}$ i Dulwich Picture Gallery ${ }^{11}$.

Dulwich to rejon Londynu słynący z wielu osobliwości: wspaniałych, rozległych, zielonych, „niemiejskich” terenów; okazałych rezydencji znanych osobistości (m.in. Margaret Thatcher); zachowanej w nienaruszonym niemal stanie ulicy handlowej z XVIII i XIX w.; ekskluzywnej szkoły Dulwich College, którą skończył, pośród wielu innych artystów, Raymond Chandler; oraz owej galerii sztuki Dulwich Picture Gallery. Mieści ona 370 dzieł przekazanych w 1811 r. przez sir Francisa Bourgeois jako początek kolekcji wraz z nowoczesną ideą jej publicznego udostępnienia. Obecnie zawiera ona

${ }^{6}$ NTK (ENTEKA, NieTyKalni) - łódzka grupa twórców istniejąca od ok. 1997 r., działająca w obszarach kultury hip-hopowej i graffiti. Obecny skład NTK podany przy okazji Bronx Hip Hop Festival 2015: MaTek, Mapet, Kliford, Zorak, DJ Goodstuffson, DJ Cider, Maru, Ovca, Dadol, Meisal461, Nova 10 Ordem, więcej na temat grupy: http://bronx.ntk.space/enteka/; https:// www.facebook.com/ENTEKA (dostęp: 17.01.2016).

${ }^{7}$ Jerzy Krawczyk, Myśli o działaniu, myśli o myśleniu, 1965, olej na płótnie, wymiary $91 \cdot 85$ cm, Muzeum Miasta Łodzi.

${ }^{8}$ Adam (Aron) Muszka, Chederowe wspomnienia (lub Reminiscencje chederowe), przed 1965, olej na płycie pilśniowej, wymiary $77.62 \mathrm{~cm}$, Muzeum Miasta Łodzi.

9 Założycielka i obecna prezeska FUF.

${ }^{10}$ The Street Art London to największa w Wielkiej Brytanii organizacja działająca w dziedzinie street artu założona w Londynie 2011 r. przez Richarda Howarda-Griffina, twórcę streetartowej galerii The Howard Griffin Gallery w Shoreditch (The East End, London); znana ze współpracy z czołowymi artystami tego gatunku sztuki, jak: RUN, Dscreet, Stik, Thierry Noir, Phlegm, ROA, NUNCA, Pablo Delgado, Liqen, REKA). The Street Art London ma także swą siedzibę w Los Angeles i działa obecnie w różnych miejscach na świecie. N.N., Baroque The Streets: Dulwich Street Art Festival 2013, 30.04.2013, [w:] Street Art London [blog], http://streetartlondon.co.uk/ blog/2013/04/30/baroque-the-streets-dulwich-street-art-festival-2013/ (dostęp: 17.01.2016).

${ }^{11}$ Patrz niżej. 
ponad 600 dzieł, w tym obrazy takich mistrzów, jak: Guido Reni, Nicolas Poussin, Peter P. Rubens, Rembrandt van Rijn, Bartolomé E. Murillo, Jean-Honoré Fragonard, Antoine Watteau, Thomas Gainsborough i wielu innych. Budynek dla daru Bourgeoisa specjalnie zaprojektował John Soane, stosując nowatorskie naówczas oświetlenie światłem dziennym wpadającym przez wysoko umieszczone okna. Dulwich Picture Gallery to także instytucja kontynuująca kulturalno-społeczne dzieło swego mocodawcy. Działa na rzecz upowszechniania sztuki, kulturalnego aktywizowania ludzi poprzez sztukę, udziela stypendiów, prowadzi programy edukacyjne, w tym dla osób starszych i młodzieży, a także przygotowuje je specjalnie z myślą o integrowaniu pokoleń. Tym sposobem włącza się w problemy przestrzeni publicznej nie tylko jako instytucja pielęgnująca tradycję, lecz także reagująca na bieżące problemy otoczenia ${ }^{12}$. Nic więc dziwnego, że w Dulwich powstała zgoła inna galeria - wspomniana wyżej Dulwich Outdoor Gallery. Autorką pomysłu dialogu street $\operatorname{artu}^{13}$ ze sztuką dawną, prowadzonego na ścianach budynków tej historycznie naznaczonej dzielnicy, jest Ingrid Beazley - mieszkająca tutaj i pracująca w Dulwich Picture Gallery kuratorka i animatorka działań społeczno-kulturalnych ${ }^{14}$. Zbiór liczy dziś 43 miejsca, w których pojedynczy twórcy lub grupy artystów pozostawili swe prace, inspirując się dawnym malarstwem, m.in. Conor Harrington, MadC, Mear One, Thierry Noir, Nunca ${ }^{15}$, Phlegm, Reka, ROA, Christiaan Nagel. Powstanie

${ }^{12}$ Na temat programu edukacyjnego Dulwich Picture Gallery zob. Dulwich Picture Gallery [witryna muzeum], http://www.dulwichpicturegallery.org.uk/learning/ (dostęp: 17.01.2016).

${ }^{13}$ Kwestie terminologiczne, np. różnicy między muralem a street artem, wykraczają poza ramy tekstu, ale sygnalizuję to jako problem na końcu artykułu.

${ }^{14}$ Jest historyczką sztuki i psycholożką, założyła też portal dla lokalnej społeczności pod nazwą Dulwich OnView (Celebrating people and culture in South London), związany oczywiście ściśle z Dulwich Picture Gallery, ale promujący nie tylko wydarzenia muzealne, lecz także wszelkie działania kreatywne, pogrupowane w następujące obszary: Culture (Art \& Design, Books \& Poetry, Dance, Music, Exhibitions, Film \& Video, Photographs, Theatre, Street Art), Life \& Style (Food \& Drink, Green Living, Health \& Fitness, Homes \& Gardens, Fashion, Gifts, Podcasts, Shopping), Around Dulwich (Dulwich Park, Local History, Local areas, South London, People, Virtual tours, Walks \& Cycling), zob. Dulwich OnView, http://dulwichonview.org.uk /who-we-are/ (dostęp: 17.01.2016).

${ }^{15}$ Praca słynnego Brazylijczyka zatytułowana Queen Bee, przestawiająca wielką pszczołę siedzącą na tronie i trzymającą sześć kubków herbaty (?), powstała w 2013 r. na ścianie w bardzo złym stanie technicznym i nie przetrwała. Była jedynym przykładem inspiracji niepłynącej z konkretnego dzieła, a raczej komentarzem do kolonializmu, zob. The Outdoor Street Art Gallery of Dulwich, [w:] Inspiring City. Random Wanderings around London looking at Street Art and other things [blog], http://inspiringcity.com/2013/05/18/the-outdoor-street-artgallery-of-dulwich/ (dostęp: 17.01.2016). W 2015 r. po renowacji obiektu powstało kolejne dzieło autorstwa MadC, tym razem inspirowane płótnem Anthony'ego van Dycka Lady Venetia Digby na łożu śmierci (1633). Zob. spis i mapę całej kolekcji: https://www.google.com/ maps/d/viewer?mid=z14gr19g41fs.kwE4ac25Rwms\&hl=en_US, oraz fanpage kolekcji na Facebooku: https://www.facebook.com/DulwichOutdoorGallery (dostęp: 17.01.2016). 
tego zbioru poprzedziło spotkanie I. Beazley w 2012 r. z londyńskim artystą o pseudonimie Stik, okrzykniętym wkrótce potem „nowym Banksym”"16. Stworzył on, wykorzystując charakterystyczne dla swego stylu uproszczone (Stik używa co najwyżej sześciu linii i dwóch punktów) postaci ludzkie, sześć $\operatorname{prac}^{17}$ nawiązujących do następujących dzieł z kolekcji Dulwich Picture Gallery: (1) Pieter Coecke van Aelst, Upadek człowieka, ok. 1520-1530; (2) Bartolomé E. Murillo, Trzech chłopców, 1670; (3) Marcantonio Franceschini, Anioł Stróż, 1716; (4) Thomas Gainsborough, Nieznana para, 1755; (5) Thomas Gainsborough, Elizabeth i Mary Linley, 1772; (6) Tily Kettle, Elizabeth i Mary Davidson, 1784. Stik w istocie przełożył na język własnego emblematu jedynie ogólne treści wyrazowe osób przedstawionych w wyżej wymienionych obrazach. Zaludnił nimi puste ściany w Dulwich, oswajając przestrzeń rozpoznawanymi postaciami, które - prawem serii - tworzą własną opowieść z udziałem siebie jako nowych bohaterów ulicy. Do dzieł malarskich murale londyńskiego artysty street artu odwołują tylko wtedy, gdy historia ich powstania (wraz z inspirującymi obrazami) jest odbiorcy wcześniej znana. Kolejne prace innych twórców, powstałe w trakcie wspomnianego „Baroque The Streets: Dulwich Street Art Festival 2013”, również miały charakter swobodnych i bardzo selektywnych nawiązań intertekstualnych.

Zgodnie z celem określonym przez I. Beazley pomysł zaangażowania artystów ulicy polegał nie na uproszczonym wykładzie z historii sztuki, objaśnianiu symboli czy przystępnej translacji, a raczej na budowaniu mostów między współczesnym street artem i sztuką w klasycznym jej rozumieniu, mostów dla nowych odbiorców obu gatunków sztuki, którzy zechcą przemierzać swą drogę $\mathrm{w}$ obie strony ${ }^{18}$. Trzeba przy tym zaznaczyć, że wymagania wobec obu grup są znacząco różne. Wielbiciel Rembrandta, wysiadając na dworcu East Dulwich, bez trudu dostrzeże, że spoglądająca z przeciwległej, wielkiej szczytowej ściany, trzymająca w dłoni spray dziewczyna ${ }^{19}$ to cytat z najcenniejszego obrazu z miejscowej kolekcji, Dziewczyny w oknie (1645), właśnie Rembrandta. Jeśli chce zobaczyć, jak inne obrazy inspirują muralistów w pozostałych przypadkach, powinien przygotować się na polisensoryczne doznania i wyruszyć odpowiednio wcześnie (by zdążył zajść potem do budynku Soane’a, który był chyba głównym celem jego podróży)

${ }^{16}$ S. Robson, Is Stik the new Banksy? Antiques dealer pays £50,000 for piece of graffiti sprayed on garage door of community centre following London riots, „Daily Mail Online”, 14.05.2013, http://www.dailymail.co.uk/news/article-2324635/Is-Stik-new-Banksy-Antiques-dealerpays-50-000-piece-graffiti-sprayed-garage-door-community-centre-following-London-riots. html (dostęp: 17.01.2016).

${ }_{17}$ Lokalizacje zob.: https://www.google.com/maps/d/viewer?mid=z14gr19g41fs.kwE4ac 25Rwms\&hl=en_US (dostęp: 17.01.2016).

${ }^{18}$ Por. N.N., Baroque The Streets...

19 Mural stworzyli w duecie Remi Rough i System. 
i w wygodnych butach. Murale ogląda się trudno ${ }^{20}$. Duża powierzchnia wymaga odpowiedniego dystansu przestrzennego, zaś by zobaczyć technikę, warto się doń zbliżyć. Trzeba się więc nachodzić. Słusznie radzi się zatem na Dulwich onView, by zabrać ze sobą aparat fotograficzny i przestrzega, że „Instagram jest super”, ale „by oddać sprawiedliwość sztuce”21, trzeba zobaczyć ją na żywo wraz z jej wartościami krajobrazowymi. Murale $\mathrm{w}$ doświadczeniu kinestetycznym zawsze zyskują, a satysfakcja $\mathrm{z}$ tego doświadczenia całkowicie umyka uwadze „bywalców” Internetu. Miłośnik street artu natomiast zyskuje zapewne dzięki muralom motywację, by zajrzeć do galerii obrazów. Tam jednak musi uzbroić się w cierpliwość i bez niewątpliwej przyjemności ruchu na świeżym powietrzu śledzić zagadki struktur dzieł dawnych mistrzów. Murale dostarczają przy tym ciekawych wskazówek, ułatwiają obserwację, uwypuklają to, czego graficzny język większości murali nie oferuje. Na przykład MadC, interpretując holenderską Martwą naturę z kwiatami ${ }^{22}$ jako dynamiczną, geometryczno-futurystyczną kompozycję, proponuje najpierw uchwycić diagonale, według których skomponowano owinięty powojami, obezwładniający szczegółami bukiet, z którego za chwilę opadną płatki zbyt rozwiniętego tulipana.

\section{ZAŁOŻENIA $^{23}$}

$\int \begin{aligned} & \text { rojekt „Off Galeria” zaadresowano do mieszkańców Starego Polesia. } \\ & \text { Jego zasadniczym celem było }\end{aligned}$

zwiększenie uczestnictwa w kulturze oraz kompetencji w jej odbiorze wśród mieszkańców obszaru zagrożonego wykluczeniem społecznym i podlegającego intensywnemu procesowi rewitalizacji ${ }^{24}$.

${ }^{20}$ Dobrze znamy ten trud z naszej gdańskiej Zaspy, zob. Murale Gdańsk Zaspa. Kolekcja Malarstwa Monumentalnego, http://muralegdanskzaspa.pl/ (dostęp: 17.01.2016).

${ }^{21}$ Cool on Demand, Stik Art Walk, Dulwich Festival... Street art in the heart of surburbia!, 05.06.2012, [w:] Dulwich OnView..., http://dulwichonview.org.uk/2012/06/05/stik-art-walkdulwich-festival-street-art-in-the-heart-of-surburbia/ (dostęp: 17.01.2016).

${ }^{22}$ Chodzi o obraz skatalogowany w Dulwich Picture Gallery jako bliżej niedatowane (XVIII w.) dzieło Jana van Huysuma. Obecnie przypisuje się je naśladowcy tego malarza - Jacobowi Xavery'emu, zob. http://www.dulwichpicturegallery.org.uk/explore-the-collection/101-150/vase-with-flowers/ (dostęp: 17.01.2016).

${ }^{23}$ Założenia projektu referuję za wnioskiem konkursowym, znajdującym się w archiwum dokumentów FUF.

${ }^{24} \mathrm{~W}$ istocie jednak przeważająca część Starego Polesia nie została włączona do planu systemowej rewitalizacji, por. http://uml.lodz.pl/rewitalizacja/badania_analizy_inwentaryzacje/ (dostęp: 17.01.2016). 
Za główne medium uznano przestrzeń publiczną jako miejsce fizyczne, konstrukt społeczny i mentalny wraz ze wszystkimi jej problemami, które mogły (i faktycznie miały ${ }^{25}$ ) wpływ na przebieg prac. Głównym narzędziem realizacji projektu zaś były murale i ich popularność oraz akceptacja wśród łodzian. Natomiast zasobem wzbogacającym działanie i integrującym z kulturalną tradycją miasta były zbiory Muzeum Miasta Łodzi. Zaproszono pięcioro twórców związanych z Łodzią i działających w mieście do stworzenia dowolnych, gdy chodzi o technikę (mural, graffiti, instalacja, mozaika itp.), wielkoformatowych dzieł inspirowanych konkretnymi obrazami. Zobowiązano twórców do udziału w spotkaniach z mieszkańcami i odniesienia się do uwag sformułowanych przez nich w trakcie warsztatów. Nie zakładano, że artyści zrealizują życzenia mieszkańców, ale że przede wszystkim poznają się i dopracują wspólnie (jeśli zajdzie taka potrzeba) projekt. Lokalizacji nie wybierano arbitralnie, a przy wsparciu staropoleskiego Stowarzyszenia Społecznie Zaangażowani, które wskazało miejsca i społeczności potrzebujące czy wprost pragnące takiej ingerencji w swojej przestrzeni. Przewidziano utworzenie w tych okolicach punktów konsultacyjnych i przeprowadzenie „Dialogów wokół murali”, będących w istocie i propagowaniem projektu, i badaniem opinii, zwieńczonym udostępnionym publicznie raportem $^{26}$. Zaplanowano też następujące wydarzenia: co najmniej jedną wizytę w Muzeum Miasta Łodzi, wycieczkę autobusową szlakiem łódzkich murali, spacer szlakiem powstałych dzieł z udziałem kuratora muzeum i przewodnika FUF oraz podsumowującą projekt wystawę z wernisażem w gmachu Muzeum.

Założono przeprowadzenie dwuetapowych warsztatów dla mieszkańców, mających wyposażyć ich w narzędzia ułatwiające odbiór sztuki oraz ocenę estetyczną przestrzeni publicznej ${ }^{27}$.

${ }^{25}$ Na przykład: dwukrotnie zmieniano lokalizację z powodu stanu technicznego muru, niedostępności dla podnośnika lub z obawy wątpliwego ostatecznego efektu (który korelowano z celami projektu); skorygowano harmonogram na skutek złej pogody, jeden artysta odmówił współpracy po interwencji mieszkańców, zob. E. Jagiełło, N. Modnicka, Projekt Off Galeria. Dialogi wokół murali, 2015, http://www.urbanforms.org/userfiles/Raport_Off_Galeria.pdf (dostęp: 17.01.2016).

26 Ibidem.

27 Program opracowały i zrealizowały A. Gralińska-Toborek i W. Kazimierska-Jerzyk z Katedry Etyki UŁ. W pierwszej części pracowano z mieszkańcami w grupach nad opisem własnego otoczenia, charakterystyką samych siebie i preferowanych wartości: na makietach w kształcie zazębiających się kół, symbolizujących trzy składniki przestrzeni publicznej (przedmiotowy, podmiotowy i aksjologiczny) zamieszczano preferowane cechy, elementy opisu itp., potem dokonywano selekcji i uzgadniano część wspólną, która była podstawą przygotowania własnej impresji plastycznej. Finalnie poszczególne grupy komentowały wzajemnie swoje prace, po raz kolejny uzgadniając stanowiska, ale tym razem między grupami. Druga część warsztatów odbywała się w plenerze przy powstających pracach oraz na wycieczkach i ostatnim spotkaniu w muzeum. Bazując na obecności artystów i dzieł, zaznajamiano uczestników z gatunkami 
Trwałym elementem edukacyjnym są tablice informujące zarówno o twórcach murali, ich motywacjach, jak i muzealnych źródłach inspiracji.

\section{REALIZACJA}

I atuszewska-Syrda, tworząc projekt, miała na myśli - w charakterze Oźródła inspiracji - Galerię Mistrzów Polskich ${ }^{28}$. Ta ekspozycja zawiera wiele przystępnych dzieł, mogących podobać się szerokiej publiczności. Ma też duży walor edukacyjny, ponieważ prace uporządkowane są w 15 tematycznych "gabinetach". Jednak kierujący muzealnym Działem Sztuki Adam Klimczak zaproponował artystom najpierw dzieła niedostępne dla publiczności, ukryte w magazynie i pomieszczeniach pomocniczych. Stworzył w ten sposób niepowtarzalną okazję do wystawienia obrazów specjalnie dla uczestników projektu oraz ponownego wprowadzenia do obiegu dzieł skazanych na zapomnienie.

Ogólnie rzecz ujmując, we wszystkich przypadkach mieszkańcy mieli duży wpływ na powstałe murale, lecz za każdym razem dotyczył on innych aspektów współpracy.

Ani wybór Madonny astronautów W. Kondka, ani nowy projekt E. Fietke nie spodobały się mieszkańcom z ul. Pogonowskiego 12. Sytuacja artysty wydawała się w pewnym momencie patowa, był przygotowany do zmiany koncepcji. Co jednak ciekawe, w trakcie pierwszych warsztatów te same osoby zainteresowały się jego mozaikami i pracami szablonowymi, podkreślały walory dekoracyjne i osobliwą zagadkowość groteskowych postaci ${ }^{29}$. Co więcej, zachwyciły się obrazami W. Kondka, ale innego typu - tymi z serii legend i scherz ${ }^{30}$. Grupa ta, pracując nad uzgodnieniem wartości wymagających ochrony w ich otoczeniu, dokonała ich radykalnej selekcji. Podkreślała, że chce sformułować przekaz maksymalnie czytelny. Za priorytet uznano bezpieczeństwo dzieci i dobrą atmosferę, w której mogłyby się one rozwijać, a którą bardzo zakłócają patologiczne zachowania i sposób użytkowania

i technikami plastycznymi, wyjaśniano różnice między sztuką tradycyjną i uliczną, pomagano wartościować zjawiska artystyczne, uzasadniać swoje wybory, podkreślano zarówno rolę intuicji czy subiektywnego wrażenia, jak i wiedzy o tradycji sztuki, ćwiczono posługiwanie się słownictwem z zakresu sztuki i architektury (skala, proporcje, kontrast, kontur, środki wyrazowe, mimika, gesty) oraz elementy analizy porównawczej dzieł i odczytywanie symboli (akcentowano ich wieloznaczność, ale i niestosowność). Szczegółowy program warsztatów wraz z efektami kształcenia oraz sprawozdania znajdują się w dokumentacji FUF oraz archiwum autorek.

${ }^{28}$ Jest to stosunkowo nowy zbiór, przekazany Muzeum w wieloletni depozyt przez mecenasa kultury i kolekcjonera sztuki Krzysztofa Musiała, dostępny od 2010 r., obejmujący 129 dzieł z lat 1846-1942.

${ }^{29}$ http://www.spaceunity.net/index.php?/01/b/ (dostęp: 17.01.2016).

30 Zob. W. Kondek, Ballady i scherza, Wydawnictwo Łódzkie, Łódź 1969. 
ich podwórka. Stąd stanowczo sformułowano oczekiwanie, aby nie podkreślać brzydoty, stymulować do zachowania czystości, motywować do renowacji otoczenia. Mieszkańcy zasugerowali, aby wykorzystać twórczość W. Kondka, dążąc w kierunku miejskiej legendy, która byłaby zrozumiała dla wszystkich. Mimo ostrego sprzeciwu spotkanie z artystą przebiegło zaskakująco. Fietke objaśniał treści wyrazowe, szkicował proste elementy, uczył, jak uzyskać żądany efekt ekspresji twarzy i gestu. Mieszkańcy zasugerowali drobną zmianę i wybrali czarno-błękitną kolorystykę malowidła. Z kolei motyw Madonny, także w przypadku W. Kondka - co zauważył Henryk Anders - interpretowany zwykle nazbyt religijnie ${ }^{31}$, zrozumiano jako bardziej uniwersalny przekaz dotyczący opieki, rodzicielstwa, bezpieczeństwa. W efekcie zamiast kolorowej bajki, która zawisłaby niczym tapeta z dziecinnego pokoju, znajdziemy tu coś naprawdę oryginalnego. Na ścianę wdrapał się genius loci, przedstawiciel inteligentnego życia z jakieś innej planety - jakby powiedział E. Fietke. Kurczowo trzyma się domu i swojego potomka, splata w sobie wszystkie części własnego mikrokosmosu niczym perfekcyjnie zakomponowany ornament. Formalnie mural przypomina Kota Taternika z Wrocławia (2014) i jest przykładem miejskiej emblematyki, charakterystycznej dla udanej, tj. rozpoznawanej sztuki miejskiej. Są to tylko z pozoru proste, konturowe figuracje, dowcipne i dwuznaczne, które - jak u Keitha Haringa - gdy zostaną zauważone, są szybko internalizowane i rozpoznawane jako żywa (apotropaiczna w swej funkcji) obecność artysty. Dwa aspekty tej współpracy są godne szczególnego podkreślenia: komunikacja z odbiorcami za pomocą sztuki i ich zaufanie do artysty ${ }^{32}$. Elementy te - choć niezbędne dla trwale cenionej sztuki miejskiej - wciąż pozostają rzadkością we współczesnych realizacjach sztuki publicznej.

Chederowe wspomnienia ${ }^{33}$ A. Muszki to oczywisty refleks pięcioletniej nauki artysty w chederze i admiracji kultury żydowskiej. Członkowie jego rodziny, w szczególności sławny dziadek, kantor ${ }^{34}$ i kompozytor Akiba

${ }^{31}$ H. Anders, Lecz inna przygoda była jeszcze piękniejsza, [w:] Wacław Kondek 1917-1976. Madonny, demony i człowieczy świat [katalog wystawy, Muzeum Historii Miasta Łodzi, Muzeum Archeologiczne, Muzeum Etnograficzne], Łódź 1996, s. 16.

32, „[... główną motywacją dla odbiorcy sztuki jest zaufanie do całkowitego zaangażowania twórcy. To ono umożliwia interpretację i gwarantuje przeżycie. Jego jakość nie zależy ani od znajomości źródeł motywów ikonograficznych, ani świadomości gatunku sztuki, przyjętej dlań definicji itp. Te aspekty podlegają nieusuwalnej społeczno-historycznej dynamice”, zob. W. Kazimierska-Jerzyk, Sztuka przestrzeni totalnej w ujęciu Keitha Haringa, [w:] Czas przestrzeni, red. K. Wilkoszewska, Kraków 2008, s. 27; K. Haring, A Real Artist is Only a Vehicle, [w:] Keith Haring, red. G. Celant, Munich-New York 1997, s. 50.

${ }_{33}$ Tytułowane i wystawiane także jako Reminiscencje chederowe, zob. Adam Muszka. Malarstwo [katalog wystawy], Warszawa 1963.

${ }^{34}$ Jego czterej synowie także zostali kantorami, zob. L. Berger, Adam Muszka, Warszawa 1970, bez paginacji. 
Muszka-Apter, także ojciec - malarz i kantor, byli jej aktywnymi twórcami. Sam Aron Muszka zaś, rozpoznawany u nas jako "Chagall z Piotrkowa” był jej propagatorem w skrajnie niesprzyjających w powojennej Łodzi warun$\mathrm{kach}^{35}$. Kameralne, pełne wdzięku, ale w dwójnasób smutne, bo - jak pisze Lili Berger - odwołujące się do tragicznej przeszłości, ale i zapowiadające tragiczną przyszłość - dzieła malarza trudno stosownie przenieść na wielką ścianę. Łódzkie muralistki skorzystały z tego, że Chederowe wspomnienia - podobnie zresztą jak motyw Madonny - oferują uniwersalne bogactwo symboliki biblijnej. Co ciekawe, A. Muszka namalował inny, bardzo podobny obraz, zatytułowany Na czym stoi świat ${ }^{36}$. Główny motyw oddzielonej, ziemsko-morskiej scenerii z jej mieszkańcami w obu przedstawieniach można więc odnieść do starotestamentowej treści z Księgi Psalmów (104: 24-26):

Jak liczne są dzieła Twoje, Panie! Ty wszystko mądrze uczyniłeś: ziemia jest pełna Twych stworzeń. Oto morze wielkie, długie i szerokie, a w nim jest bez liku żyjątek i zwierząt wielkich i małych. Tamtędy wędrują okręty, i Lewiatan, którego stworzyłeś na to, aby w nim igrał ${ }^{37}$.

Po spotkaniu z mieszkańcami artystki, które miały zająć się trudną technicznie podwójną ścianą, otrzymały dodatkowe, konkretne sugestie. Ta grupa warsztatowa skoncentrowała się na sporządzeniu swoistej recepty dla tego miejsca o ciekawej architekturze, ale wymagającej innego spojrzenia, wysiłku dostrzeżenia tej urody. W przygotowanej impresji plastycznej nie wyrażono więc - jak poprzednio - środowiska i mieszkańców, a stworzono zbiór zaleceń. Uznano za konieczne włączenie elementu kulturowego w postaci znanego motywu ikonograficznego Jonasza, który ożywiałby to miejsce, wprowadził narrację, nadał sens przez optymistyczną opowieść: „chcemy dać ludziom pewność, że teraz to osiedle i Łódź będą szły tylko w górę" ${ }^{38}$. Dotkliwą ponurość okolicy sugerowano zniwelować użyciem farb luminescencyjnych. Współautorka muralu Aleksandra Adamczuk w trakcie muzealnego spotkania przyznała, że ta rada dotycząca treści, jak i formalna sugestia korespondencji obu ścian były bezcenne do tego stopnia, że zdominowały przyszły projekt. Malarki nie konkurowały przy tym z nastrojowymi światłocieniem A. Muszki, ogromne powierzchnie pokryły ażurowym konturem przestawiającym Jonasza podążającego w stronę miasta ujętego - tym

35 M.A. Supruniuk, Chagall z Piotrkowa. Adam Muszka (1914-2005), „Archiwum Emigracji. Studia - Szkice - Dokumenty" 2006, nr 1-2 (7-8), s. 310-311.

${ }^{36}$ Obraz jest reprodukowany w książce L. Berger, Adam Muszka ..., bez paginacji.

37 Biblia Tysiąclecia Online [tekst wyd. 4 papierowego], Poznań 2003, http://biblia.deon. $\mathrm{pl} /$ menu.php?st_id=1.

${ }^{38}$ Cytat z makiety stworzonej przez mieszkańców w trakcie warsztatów. 
razem jak w inspirującym pierwowzorze - w górnym pasie kompozycji, w charakterze nokturnu.

Grafficiarze, wybierając obraz J. Krawczyka, zachwycili się jego kolorystyką. Meisal461 stwierdził, że płótno nie miało sobie równych, gdyż $\mathrm{w}$ pozornie jednorodnej tonacji łódzki realista ukrył, widoczne $\mathrm{z}$ bliska, zaskakujące bogactwo barw. Nie bez znaczenia pozostały też wartości iluzyjne sztuki J. Krawczyka i jego doskonała technika. Zarówno Meisal461, jak i Ovca definiują siebie jako rzemieślników, stale doskonalących swój warsztat, eksperymentujących z różnymi technikami i materiałami. Przyznają też, że o niewielu swoich pracach mogą powiedzieć, że ich satysfakcjonują. Ta analogia jest ciekawa. Często bowiem cytuje się sugestywne wspomnienie Bożeny Kowalskiej, która widziała w pracowni artysty dzieła malowane różnymi historycznymi technikami, które Krawczyk pomimo pieczołowitego wykończenia, traktował tylko jako techniczne wprawki ${ }^{39}$. Inni, w kontraście do tej anegdoty, akcentują więc, że

bezzasadne [...] wydaje się przypisywanie J. Krawczykowi tendencji sensualistycznych. Choć pieczołowicie odtwarzał wyglądy rzeczy, kierował się głównie intelektem ${ }^{40}$,

interesował się reizmem Tadeusza Kotarbińskiego, a jego konceptualizacja malarstwa na długo uprzedza hiperrealizm ${ }^{41}$. Zagadnienia ontologiczne oraz refleksja nad konstytutywnymi elementami sztuki nie miały, jak sądzę, znaczenia w swoistej parafrazie, jakiej dokonali Meisal461 i Ovca. Warto jednak zwrócić uwagę na dwa inne elementy tej realizacji. Po pierwsze, ze wszystkich trzech najbliższa jest pierwowzorowi - zachowano strategię kolażu i obrazu w obrazie; utrzymano trywialność motywów życia codziennego, a realizm codzienności podkreślono, zamieniając atrubuty; urealniono i czas, i miejsce, i autorów - wszak widzimy tag na murze; uspójniono wewnętrzny świat obrazu przez dodanie definicji graffiti i muralu ${ }^{42}$. Po drugie, nie jest obce łódzkim grafficiarzom myślenie metaartystyczne ${ }^{43}$. Sławomir Krysiak, wmontowując swój tag „Sławek” w tło obrazu i cytując powszechnie przyjmowane definicje sztuk ulicznych, zwraca uwagę, jak

${ }^{39}$ B. Kowalska, Jerzy Krawczyk [plakat / katalog wystawy, Galeria 72, Chełm], Chełm 1982.

${ }^{40}$ H. Anders, bez tytułu, [w:] Jerzy Krawczyk (1921-1969). Malarstwo, rysunek, grafika [katalog wystawy, Muzeum Historii Miasta Łodzi, Galeria Łódzka], Łódź 1987, s. 21.

${ }^{41}$ G. Musiał, bez tytułu, [w:] Jerzy Krawczyk. Malarstwo [katalog wystawy, Galeria Sztuki Współczesnej w Łodzi, Targi Sztuki Współczesnej CONTART], Łódź 1977, bez paginacji.

${ }^{42}$ Por. cechy wyodrębnione przez Hugona Aulera: idem, Jerzy Krawczyk - nowy wymiar malarstwa sztalugowego, „Correio Braziliense”, 06.04.1968, tłum. M. Hołyńska, maszynopis ze zbiorów biblioteki Muzeum Sztuki w Łodzi, teczka 529/1, s. 11-14.

${ }^{43}$ Ibidem, s. 20. 
jedna technika przekształca się w drugą, traci swoiste funkcje, a zyskuje inną przestrzeń rozwoju. W tym samym czasie tag Meisala461 rozbłysnął w centrum kompozycji na rogu ulic Północnej i Zachodniej, która w konwencji reklamowej propagowała twórców Bronx Hip Hop Festival 2015. Zaś na spotkaniu w muzeum Paweł Hert podkreślał, że ten rodzaj napięcia pomiędzy twórczością komercyjną i zamawianą a korzeniami graffiti stale towarzyszy im w pracy ${ }^{44}$. Oczywiście tego typu dylematy, a z drugiej strony - symbiotyczne relacje sztuki z komercją, to chleb powszedni plastyki już od czasów klasycznej awangardy. Eksperyment „Off Galerii” podkreślił, jakie inne jeszcze przemieszczenia dokonują się w świecie sztuki. Paradoksem chyba jest, że mural Meisala461 i Ovcy, choć przyjęty z entuzjazmem po odrzuceniu pierwotnej propozycji innego artysty ${ }^{45}$, jest najmniej rozumiany przez lokalną społeczność. Uświadomili mi to uczestnicy kolejnych warsztatów, odbywających się Starym Polesiu przy innych okazjach. Ta refleksja metaartystyczna czy synkretyczne zestawienie elementów, które próbowałam objaśniać, były dla moich rozmówców tak dalece nudne, że aż niemożliwe jako uzasadnienie treści muralu. Tym bardziej warto podkreślić, że w przekonaniu S. Krysiaka i P. Herta, ich udział w projekcie to międzypokoleniowy hołd dla uniwersalnych, wspólnych wartości sztuki, do których należy m.in. warsztat ${ }^{46}$.

Hołdem dla odbiorców był natomiast muzealny wernisaż. Wystawione w sali lustrzanej pałacu Izraela Poznańskiego, rzadko widziane dzieła W. Kondka, J. Krawczyka i A. Muszki kontrastujące swą skromnością i z tym wnętrzem, i skalą murali, wystawiły na próbę najbardziej wybrednych odbiorców.

Podobne rozmiarami, lecz całkowicie odmienne w stylistyce i tematyce obrazy utworzyły tryptyk poświęcony polskiej sztuce lat sześćdziesiątych. Rozmowa na temat każdego z nich z udziałem artystów (co pozostaje rzadkim przywilejem) i z perspektywy twórczego nawiązania do przeszłości była rodzajem świętowania, które w doświadczeniu sztuki prawie utraciliśmy ${ }^{47}$.

${ }^{44}$ Artyści są autorami kontrowersyjnego muralu z Marcinem Gortatem, a Meisal461 jest współautorem lubianej przez łodzian alegorii miasta przy ul. Piotrkowskiej 152. Obaj pracują, wykonując różnego typu iluzjonistyczne prace. Ovca jest cenionym, wielokrotnie nagradzanym w Europie specjalistą w technice airbrush.

45 Zob. E. Jagiełło, N. Modnicka, op. cit., s. 30.

${ }^{46}$ Zob. tablicę informacyjną z wypowiedzią artystów. Deklaracja ta ciekawie koresponduje ze znanym manifestem Krawczyka, dotyczącym m.in. tolerancji wobec innych twórców, zob. Krawczyk J., bez tytułu, [w:] Jerzy Krawczyk - malarstwo. Janusz Tusiński - grafika [katalog wystawy, Ośrodek Propagandy Sztuki, Łódź] Łódź 1958, przedruk w: Jerzy Krawczyk (1921-1969). Malarstwo, rysunek, grafika, s. 45-46.

47 R. Bubner, Doświadczenie estetyczne, tłum. K. Krzemień, Warszawa 2005, s. 176-177. 


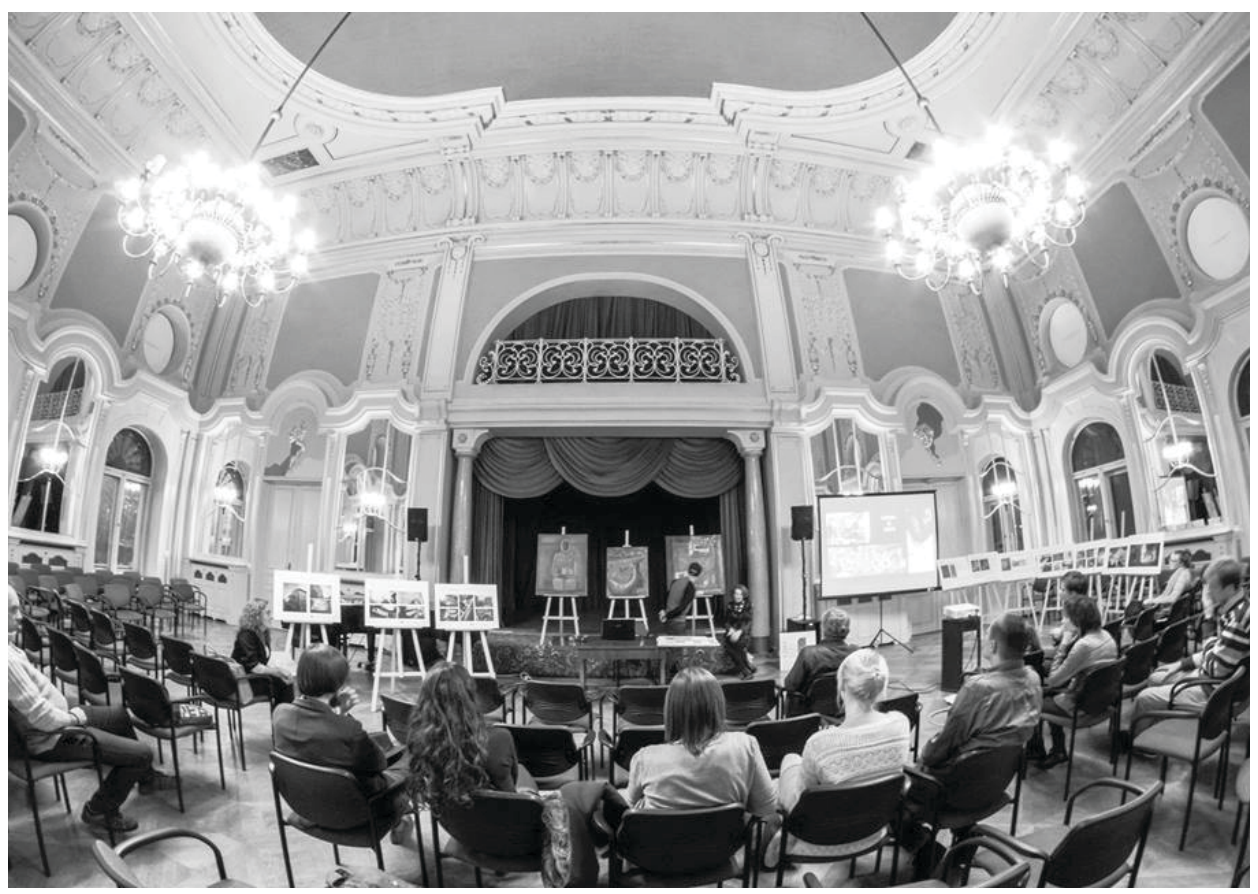

Ryc. 50. Wystawa dzieł Madonna astronautów Wacława Kondka, Myśli o działaniu, myśli o myśleniu Jerzego Krawczyka, Chederowe wspomnienia Adama Muszki i wernisaż w dniu zamknięcia projektu „Off Galeria”, Muzeum Miasta Łodzi, 17.10.2015

\section{POLEMIKI (ZAMIAST ZAKOŃCZENIA)}

\section{Jak ocenić stopień realizacji celów „Off Galerii”?}

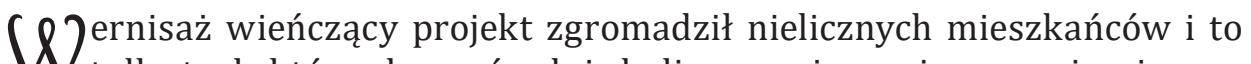
tylko tych, którzy bezpośrednio byli zaangażowani w organizację projektu. Spróbujmy uchwycić więc główne relacje pomiędzy jego podmiotami (zob. poniższy diagram). Muzeum jest instytucją, z którą wiążą się przede wszystkim teoretycy i organizatorzy, same dzieła interesują już - można powiedzieć - tylko stałych bywalców. Mieszkańcy bratają się ze sztuką za pośrednictwem aktywnie działających, społecznie wrażliwych artystów i obecnych w ich środowisku animatorów społecznych. Teoretycy, podobnie jak Fundacja, choć są dostarczycielami idei, mają dostęp do mieszkańców dziękiartystomianimatorom,korzystajązzaufaniadonich, niedosamychidei.

Jeśli miałby to być koniec tej inicjatywy, to niczego ona nie zmienia. Jeżeli jednak jest to jej początek, sytuacja jest już rozpoznana: trzeba zadbać o lepszą motywację do przekroczenia progu muzeum. Może byłby w stanie ją 
wzmocnić - jak w Dulwich - lokalny portal internetowy obejmujący wszelką aktywność kulturową od kulinariów po wystawy mistrzów ${ }^{48}$ ?

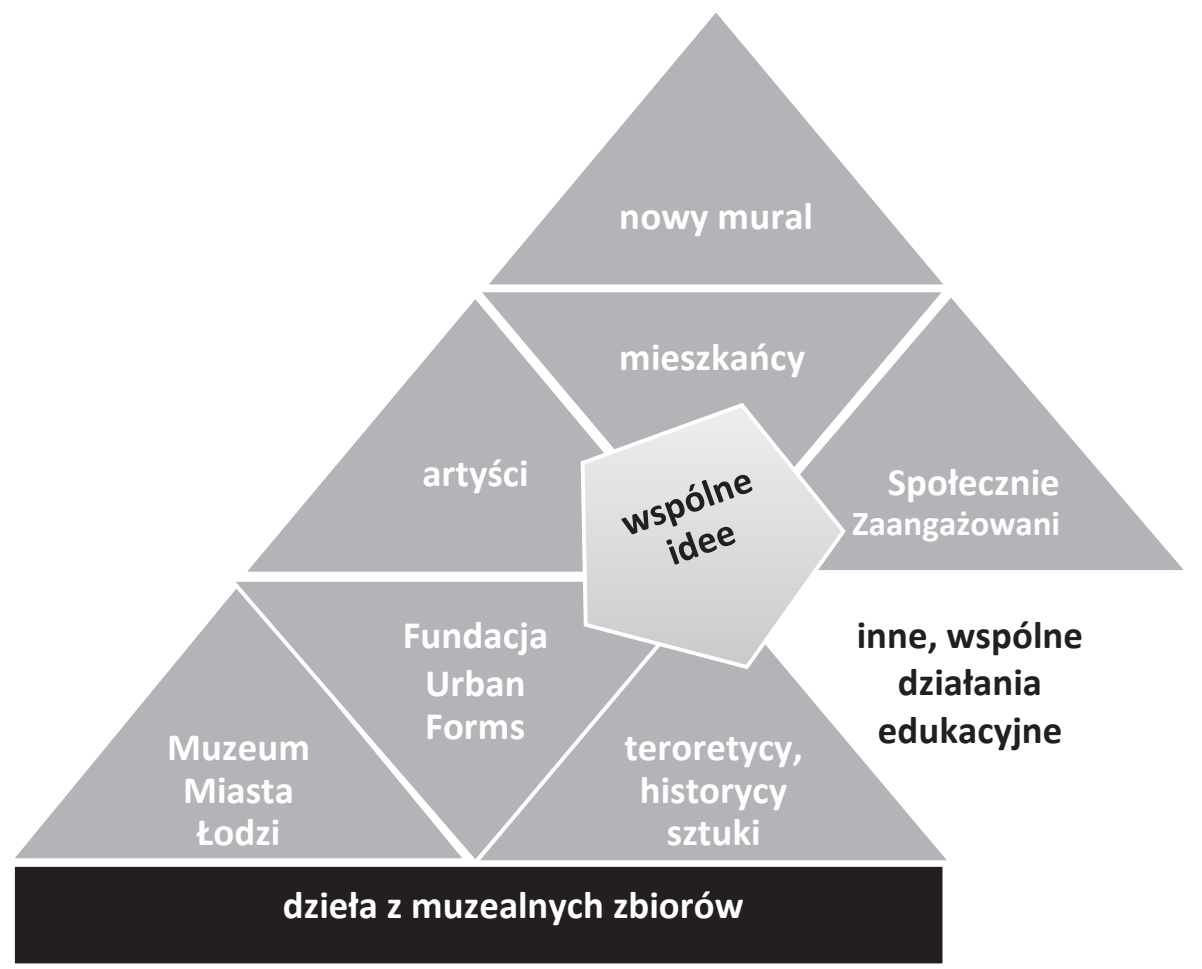

Ryc. 51. Struktura relacji między podmiotami zaangażowanymi w projekt „OFF Galeria 2015” oraz związków tych podmiotów ze sztuką muzealną i muralami. Opracowanie własne autorki

Raport podsumowujący „Dialogi wokół murali” demaskuje niewiedzę mieszkańców na temat sztuki w przestrzeni publicznej i brak zdolności spontanicznego komunikowania się na jej temat. Sądzę, że ta obserwacja jest chybiona. Po pierwsze, wskazane przez rozmówców przykłady są poprawne, a sztuka publiczna (służąca i fizycznej przestrzeni miasta, i ludziom) w Łodzi to jeden z dotkliwszych braków tego miasta, zarówno pod względem ilości, monotonii, jak i jakości. Po drugie, przy dzisiejszym, powszechnym dostępie do wiedzy trudno jednoznacznie mówić o niekompetencji odbiorców. Szczególnie przygoda mieszkańców z A. Miastkowskim

${ }^{48}$ Zob. przypis nr 14. Na temat community centers zob. np.: EuCDN launches its framework for community development throughout Europe, wyd. European Community Development Network, 2014, wersja polska: Rozwój społeczności lokalnych w Europie. W kierunku wspólnych założeń i rozumienia, red. P. Jordan, http://eucdn.net/wp-content/uploads/2014/11/CAL_ publikacja_ost-polish2.pdf (dostęp: 17.01.2016). 
pokazuje, jak łatwo zyskać orientację w kwestiach dotyczących artystów i ich dzieł, znaleźć argumenty, by bronić swego zdania, a mając dobrego przewodnika - skorygować własne przeświadczenie.

\section{Jak oceniać powstałe dzieła?}

Wiele ostatnio powiedziano o złych intencjach twórców murali i organizacjach wspierających tę sztukę, o niewybrednych gustach masowej, miejskiej publiczności, ale... z perspektywy arbitralnie przyjętych kryteriów street $\mathrm{artu}^{49}$. Spośród wszystkich przywoływanych w tym artykule przykładów - nie licząc K. Haringa - tylko nieistniejący mural Nunci ${ }^{50}$ charakteryzował się owym przekroczeniem i wkroczeniem na czyjś teren (trespass), które bawią tylko wówczas, gdy wiemy, że innych drażnią do tego stopnia, iż dzieła dokonujące tych przekroczeń zostaną zlikwidowane ${ }^{51}$. Murale, o których tu mowa, są społeczną inwestycją, która ma inne cele niż street art i powinna w związku z tym być inaczej oceniana - z perspektywy realizacji tych społecznych celów. Co nie znaczy, że proces tej oceny nie obejmuje wartości artystycznych i estetycznych. Gdy mieszkańcy pertraktujący z E. Fietke jednogłośnie wybrali czarny mural (nie „ładny”, „żywy” itp.), było jasne, że stereotypy najlepiej funkcjonują w ramach niesprawdzonych uogólnień. I nie był to przypadek. Wcześniej, w trakcie warsztatów, uzgadniając preferowane wartości, ludzie ci wyrzucili poza nawias swej ochrony m.in. piękno, bogactwo i... parking, zostawili estetykę (rozumianą jako decorum), bezpieczeństwo, przestrzeń, zieleń, czystość i ciszę.

\section{Ile jeszcze może powstać tych murali?}

Niedługo po tym, jak E. Fietke skończył pracę na ul. Pogonowskiego 12 nad swoim „rozjechanym kotem” ${ }^{2}$, mieszkańcy odnowili cokołową część budynku, której nie obejmuje malowidło. Znajduje się w niej główne wejście do kamienicy. Teraz flankują je dwaj zwróceni ku sobie „Łowcy prani”, wykonani przez artystę - dla odmiany - techniką szablonową. Strzegą domu, bawią i zdumiewają nowych gości swymi kotowatym ciałami z wirnikowym bębnem wewnątrz. Podobno pan Tomek ma jeszcze jednego na szafie.

${ }^{49}$ S. Frąckiewicz, Żeby było ładnie. Rozmowy o boomie i kryzysie street artu w Polsce, Poznań 2015, s. 5-6.

${ }^{50}$ Por. przyp. 15.

${ }^{51}$ C. McCormick, M. Schiller, S. Schiller, E. Seno, Trespass. A History of Uncommissioned Urban Art, Köln 2010, s. 132.

${ }^{52}$ Cytat z pierwotnych opinii mieszkańców o projekcie artysty. 
Gdy codziennie wychodzę z mojego domu i rzucam okiem (muszę, nie mam wyboru ${ }^{53}$ ) na mural zaburzający proporcje pięknego, lecz okaleczonego z detali budynku (autorstwa znanego architekta z początku XX w.), $\mathrm{w}$ dodatku powielający motyw wykonany w tym samym roku w Australii, mam ochotę krzyknąć „JUŻ DAWNO DOŚĆ!”, ale obserwując widok z okna na pustą ścianę, wyobrażam sobie, że cieszyłby mnie energetyczny przedstawiciel z kosmicznej menażerii Egona. Rzecz w tym, że murale są w najwyższym stopniu sztuką kontekstu. Podstawowe czynniki, które go tworzą, to: historia miejsca, struktura architektoniczna i urbanistyczna miejsca, bieżące i przyszłe inwestycje, deficyty estetyczne (koloru, przestrzeni, różnorodności), poczucie przynależności do domu, okolicy, ulicy, wspólnota wartości. Murale powinny powstawać tam, gdzie sprzyjają im te czynniki, gdzie miejsca i ludzie potrzebują obrazów i ich działania.

\section{BIBLIOGRAFIA}

Adam Muszka. Malarstwo [katalog wystawy], Warszawa 1963.

Adamczewska I., Stare Polesie. Aktywiści zmieniaja je bez pomocy miasta, „Gazeta Wyborcza” 27.06.2014, http://lodz.wyborcza.pl/lodz/1,35153,16225354,Stare_Polesie_Aktywisci_zmieniaja_je_bez_pomocy_miasta.html\#ixzz3yq3SELq7 (dostęp: 17.01.2016).

Anders H., bez tytułu, [w:] Jerzy Krawczyk (1921-1969). Malarstwo, rysunek, grafika [katalog wystawy, Muzeum Historii Miasta Łodzi, Galeria Łódzka], Łódź 1987.

Anders H., Lecz inna przygoda była jeszcze piękniejsza, [w:] Wacław Kondek 1917-1976. Madonny, demony i człowieczy świat [katalog wystawy, Muzeum Historii Miasta Łodzi, Muzeum Archeologiczne, Muzeum Etnograficzne], Łódź 1996.

Auler H., Jerzy Krawczyk - nowy wymiar malarstwa sztalugowego, „Correio Braziliense”, 06.04.1968, tłum. M. Hołyńska (maszynopis ze zbiorów biblioteki Muzeum Sztuki w Łodzi, teczka 529/1).

Biblia Tysiąclecia Online [tekst wyd. 4 papierowego], Poznań 2003, http://biblia.deon.pl/ menu.php?st_id=1.

Berger L., Adam Muszka, Warszawa 1970.

Bubner R., Doświadczenie estetyczne, tłum. K. Krzemień, Warszawa 2005.

Cool on Demand, Stik Art Walk, Dulwich Festival... Street art in the heart of surburbia!, 05.06.2012, [w:] Dulwich OnView [portal społecznościowy], http://dulwichonview.org. uk/2012/06/05/stik-art-walk-dulwich-festival-street-art-in-the-heart-of-surburbia/ (dostęp: 17.01.2016).

Dulwich OnView [portal społecznościowy], http://dulwichonview.org.uk/who-we-are/ (dostęp: 17.01.2016).

${ }^{53}$ Na temat przymusu doświadczenia murali zob. A. Gralińska-Toborek, W. Kazimierska-Jerzyk, op. cit., s. 33-39. 
Dulwich Outdoor Gallery [fanpage kolekcji], https://www.facebook.com/DulwichOutdoorGallery (dostęp: 17.01.2016).

Dulwich Outdoor Gallery [spis i mapa całej kolekcji], https://www.google.com/maps/d/viewer?mid=z14gr19g41fs.kwE4ac25Rwms\&hl=en_US, (dostęp: 17.01.2016).

Dulwich Picture Gallery [witryna muzeum], http://www.dulwichpicturegallery.org.uk/ learning/ (dostęp: 17.01.2016).

EuCDN launches its framework for community development throughout Europe, wyd. European Community Development Network, 2014; wersja polska: Rozwój społeczności lokalnych w Europie. W kierunku wspólnych założeń i rozumienia, red. P. Jordan http://eucdn.net/wp-content/uploads/2014/11/CAL_publikacja_ost-polish2.pdf (dostęp: 17.01.2016).

Gralińska-Toborek A., Kazimierska-Jerzyk W., Doświadczenie sztuki w przestrzeni miejskiej. Galeria Urban Forms 2011-2013 / Experience of Art in Urban Space. Urban Forms Gallery 2011-2013, tłum. M. Koniarek, Łódź 2014.

Haring K., A Real Artist is Only a Vehicle, [w:] Keith Haring, red. G. Celant, Munich-New York 1997.

Egon Fietke [strona artysty], http://www.spaceunity.net/index.php?/01/b/ (dostęp: 17.01.2016).

Jagiełło E., Modnicka N., Projekt Off Galeria. Dialogi wokół murali, 2015, http://www.urbanforms.org/userfiles/Raport_Off_Galeria.pdf (dostęp: 17.01.2016).

Kazimierska-Jerzyk W., Sztuka przestrzeni totalnej w ujęciu Keitha Haringa, [w:] Czas przestrzeni, red. K. Wilkoszewska, Kraków 2008.

Kondek W., Ballady i scherza, Łódź 1969.

Kowalska B., Jerzy Krawczyk [plakat / katalog wystawy, Galeria 72, Chełm], Chełm 1982.

Krawczyk J., bez tytułu, [w:] Jerzy Krawczyk - malarstwo. Janusz Tusiński - grafika [katalog wystawy, Ośrodek Propagandy Sztuki, Łódź], Łódź 1958.

Łódzkie murale [witryna internetowa], http://www.murale.mnc.pl/m_072.htm (dostęp: 17.01.2016).

McCormick C., Schiller M., Schiller S., Seno E., Trespass. A History of Uncommissioned Urban Art, Köln 2010.

Musiał G., bez tytułu, [w:] Jerzy Krawczyk. Malarstwo [katalog wystawy, Galeria Sztuki Współczesnej w Łodzi, Targi Sztuki Współczesnej CONTART], Łódź 1977.

N.N., Baroque The Streets: Dulwich Street Art Festival 2013, 30.04.2013, [w:] Street Art London [blog], http://streetartlondon.co.uk/blog/2013/04/30/baroque-the-streets-dulwichstreet-art-festival-2013/ (dostęp: 17.01.2016).

Robson S., Is Stik the new Banksy? Antiques dealer pays £50,000 for piece of graffiti sprayed on garage door of community centre following London riots, „Daily Mail Online”, 14.05.2013, http://www.dailymail.co.uk/news/article-2324635/Is-Stik-new-Banksy-Antiques-dealerpays-50-000-piece-graffiti-sprayed-garage-door-community-centre-following-Londonriots.html, (dostęp: 17.01.2016).

Stępień B., Łódzkie murale. Niedoceniona grafika użytkowa PRL-u, Łódź 2010.

Supruniuk M. A., Chagall z Piotrkowa. Adam Muszka (1914-2005), „Archiwum Emigracji. Studia - Szkice - Dokumenty" 2006, nr 1-2 (7-8), s. 310-312. 
The Outdoor Street Art Gallery of Dulwich, [w:] Inspiring City. Random Wanderings around London looking at Street Art and other things [blog], http://inspiringcity.com/2013/05/18/ the-outdoor-street-art-gallery-of-dulwich/ (dostęp: 17.01.2016).

Wspót-dzielnia Staropoleska [fanpage organizacji], https://www.facebook.com/wspoldzielniastaropoleska (dostęp: 17.01.2016).

\section{SUMMARY}

\section{Masterpieces of Traditional Easel Painting as an Inspiration for Modern Murals - “Off Gallery Project” (2015)}

The text discusses the complex characteristics of the activities of the Urban Forms Foundation during realisation of "The Off Gallery Project". It was organised to create murals that were interpretations of the pictures included in the Gallery of Polish Masters (Museum of the City of Łódź). It also served to increase participation in culture and competence of the perception of art among residents of the areas threatened by social exclusion. In addition to the workshops and the creation of murals, the Off Gallery was enriched by participatory elements, which was a very new and non-typical form of the activity of the Foundation. 